an ascendancy and even an actual or presumptive international position with regard to scientific publication. For example, the Internationale Revue der gesammien Hydrobiologie und Hydrographie is published in Leipzig, and it must be confessed that it is conducted with considerable ability and adequately fulfils its function. Such works, too, as the "Nordisches Plankton" show how keen our present enemies have been in publishing monographs which have become indispensable. It is not necessary, however, to look for sinister intentions in the progress which Germany has made in publication. In all countries scientific literature has had a similar history, and its evolution may be said to mark the progress made by each with respect to science. In all countries, societies, museums, and laboratories have sought an outlet for their investigations by publications which have the primary advantage of securing by exchange similar publications from institutions at home and abroad.

The result is somewhat chaotic, and for this reason we are thankful to the societies and publications and agencies which attempt to give us periodical lists of literature and summaries of papers. I confess I do not see how the national output of scientific papers is to be controlled, or, indeed, if it is desirable that it should be controlled. This is a matter which it appears must be left to the editor and the writer. But now that our attention has been directed to the subject, the opportunity should be taken to discuss whether we should be content with pre-war conditions, or if improvements could be suggested so far as the nation is concerned, and especially with regard to the control of such publications as are meant to be international in character. We have to recognise that each country must necessarily have an output of material for publication for which provision must be made. The fact that so many English papers have been published in Germany raises the question whether the provision is adequate. It might be suggested that each country should publish its own material, and that the desirability of publishing year-books bringing together summaries of the important papers and discoveries in each subject should be considered. If this were done by each country, probably the necessity for international journals would disappear, and better so, for it would be difficult to determine in each case which country and which language to choose.

An improvement of great value would result if a suggestion which has been made before were carried into effect, viz. that a size of page for octavo and for quarto periodicals should be decided upon. If this were agreed to by each country, and the effort made to issue the more monographic papers separately, it would be possible to bind in any way suitable to the institution or worker.

Armstrong College, Newcastle-upon-Tyne,

$$
\text { January } 27 .
$$

\section{Science in Education.}

ON p. 432 of your issue for February $I$ it is stated in an unsigned article that "in the early fifties of the nineteenth century a little experimental science crept in almost shamefacedly, introduced by the peripatetic teacher with his box of tricks." Then after mentioning Queenwood in 1847 it goes on: "But it was not. until twenty years later that this example was followed in other schools. Then Clifton took the lead in 1867 , and was followed immediately by the Manchester Grammar School."

Your correspondent is not very well informed.

At Rugby in $r 849$ William Sharp, F.R.S., was appointed by Dr. Tait reader in natural philosophy, and gave systematic teaching to classes of boys. He was succeeded by Henry Highton, a distinguished NO. 2468 , VOL. 98] electrician (see Arago's "Tonnerre"), who taught chemistry and physics to about forty boys. He became headmaster of Cheitenham College in 1859, and Dr. Temple appointed me to succeed him. A chemical laboratory was built, and I taught physics, chemistry, and a little geology to somewhat larger classes. Then in ${ }^{186}$, after the Public Schools Commission, a great increase in science teaching took place; the Rev. T. N. Hutchinson was appointed to take chemistry, and Mr. Kitchener took botany with large classes. I went on with physics and geology. All this happened before 1867 .

Clifton College is an excellent school, but it need not be exalted at the expense of its mother.

JAMES M. WILSON,

Sometime mathematics and science master at Rugby, and afterwards headmaster of Clifton College.

Oвviously the article referred to did not profess to give a complete history of the introduction of science teaching into schools. That would be a long story, and would nècessitate reference to several schools besides Queenwood, such as the Friends' School at Ackworth, in Yorkshire, where for many years some teaching of science subjects had been established long before Rugby and other public schools had made a beginning. The claim for Clifton is based on the fact that it is believed to have been the first great school in which natural science was introduced as a constituent of the curriculum imposed on the whole school (except the Classical VI.), and not as a voluntary subject taken up by a small number of boys as an alternative to modern languages or other subjects, as was the case at Rugby in 1859 .

The Writer of the Article.

\section{"Frost Thistles."}

In Nature of January ir Dr. R. T. Gunther describes a very beautiful freezing effect. I recently obtained a similar effect on a much larger scale. One of the large bottles, holding several litres, used for collecting rainfall in the London parks, in connection with the investigation of atmospheric pollution, was found, when brought into the laboratory for examination, to contain a hollow cylinder or annulus of ice, perforated with silvery air-tubes arranged, as Dr. Gunther remarks, for all the world like lines of force round a magnetic pole. We were unable to detect any visible speclus of solid matter at the peripheral ends of the tubes; but these ends were pointed, whereas the inner ends were rounded and expanded, probably terminating thus where ice and the central core of water met. The surface of this central portion was covered with a scum of air-bubbles. One feature which was noticed particularly was that, in addition to the air-tubes, other channels filled with something (probably liquid water containing dissolved matter) were arranged radially throughout the mass.

The water represented the accumulated rainfall of January, and, in addition to matters in solution, contained an appreciable deposit. It is, therefore, quite probable that small particles were present on the sides, and thus formed collecting points for the air first liberated when congelation began.

The various points observed agreed entirely with those already described, except that the very much larger quantity of water had not solidified throughout its mass. If this had occurred it would have probably been a slow action and the opaque central mass would not have been seen.

Teddington, February.

Note.-Since writing the above I have seen another mass of ice solid throughout, which had broken the bottle; a small opaque central cylinder, or inverted cone, was observed.--J. H. C. 